\title{
INVESTIGATING THE NEXUS BETWEEN MUTUAL FUND RETURN AND STOCK MARKET PERFORMANCE - EVIDENCE FROM PAKISTAN STOCK EXCHANGE
}

\author{
Muhammad Tariq \\ Manager $(R \& D)$, Institute of Business Management \\ Faizan Ehtesham \\ Research Scholar, Ilma University and Capital Market Analyst
}

\begin{abstract}
Purpose: This study is aimed to determine the nexus between mutual fund returns and stock market returns in Pakistan. This study adds contribution by testing the causa-effect relation of mutual fund returns and macroeconomic factors on the stock returns in Pakistan.

Methodology: This study is based on Panel data for 10 AMCs operating in Pakistan and macroeconomic factors for the period of 2007 to 2016. The hypothesis testing is based on panel data analysis, therefore the panel regression is applied via PLS, FEM and REM comparison.

Findings: The study concludes that the there is significant effect of Equity Funds Returns on Stock Return. On the other hand, debt funds return and T-bills have the insignificant impact on Stocks Return.

Policy Implication: This study recommends influential findings for the policy makers such as equity funds have positive effect on the stock market
\end{abstract}

Keywords: Mutual Fund and Stock Market Stability, Debt Fund, Equity Fund

Jel Classification: F3, G1, G2.

*The material presented by the author does not necessarily portray the view point of the editors and the management of the Ilma University - Formerly IBT

1. Muhammad Tariq : : m.tariq@iobm.edu.pk

2. Faizan Ehtesham : faizanehtesham@gmail.com

CILMA-JBS is published by the Ilma University - Formerly IBT

Main Ibrahim Hydri Road, Korangi Creek, Karachi-75190, Pakistan 


\section{INTRODUCTION}

\subsection{Overview}

Pakistan has remarkable growth in the Mutual Fund Market industry with net asset value increased from Rs 16 billion in 1999 Rs 137 billion in 2005. However, the market share of this sector in Pakistan is very small, it holdsonly $1.33 \%$ of assets consists of mutual funds.The regional comparison depicts that to India, South Korea, Hong Kong and Malaysia, and with percentage of $3.7 \%, 16.5 \%, 20.3 \%$ and $4 \%$ respectively. These numbers show that Pakistani mutual industry has momentous room to grow and now in January 2016 total asset under management as per Mutual Fund Association Pakistan about Rs. 452,305,918,000 (MUFAP, 2016). Mutual Funds provides access on professional asset management services with diversified investment products i.e. equity funds, money market funds, debt funds etc. the various investment options provided by the mutual fund industry is to make small investors to easy to access on investment in shares through mutual funds. The mutual funds units can be purchased or redeemed on net asset value basis that is announce on daily

Pakistan Stock Exchange touching its new highs on the threshold of classification into Morgan Stanley Capital International (MSCI) Emerging Market and subsiding foreign selling. 7 years back in 2008, Pakistan had been removed to MSCI's emerging market category and fall into frontier market. Pakistan is now all set to be reclassification into MSCI's Emerging Market Category. After the reclassification of Pakistan into Emerging Market Category the Pakistan Stock Market continue touches its new highs. KMI-30 index appreciated by $25.61 \%$ in calendar year to October 10, 2016, extracted from fund manager report November 2016 of Al Meezan Investment Management Limited and market update note from the desk of Chief Investment Officer of Al Meezan Investment Management customers.

The emerging issue is that what will the effect of outflow on stock market when these injection of fund withdrawal from the market. In this study we analyze the effect of inflows and outflows on stock market return and effect of macro state factors on stock return.

Goetzmann and Massa (2003), research on "Index Funds and Stock Market Growth" and concluded that parallel correlation between inflows and return, in context of negative market return it persuade the consequent sale. The efficient development of mutual fund in Pakistan raised the demand about the influence of mutual fund flows on stock market stability. Many have a confident in about the hype of equity market of 1990s is due to the injection of fund from mutual fund to equity market and the withdrawal of those funds could send the stock pricing dropped R. Edwards (1996). The theory of efficient market hypothesis (EMH) suggested that the current pricing of stock fully reflect the valuation of the firm on the basis of the information floated in the market. There is no other way to earn excess profit by the help of the current information. The market efficiency hypothesis theory describes the how information on stock market about the firm will impact on valuation of the firms (Fama, 1965). The EMH suggests that the gain on behalf of the price prediction and movements is very difficult, the basic mechanism is in behind of the price fluctuation is the arrival of information about the securities that affect the price of the firm securities. The current price of any security is based upon the all available information, consequently, there is no reason to have faith in the price is too high or low(Fama, \& French, 1992). The security prices are adjusted before the trade or profit from the new piece of information. There are three forms of 
efficient market hypothesis, which are weak efficiency, semi efficiency and strong efficiency. The weak form of the EMH describe the past history of the security price on the basis of the all incorporated information is reflect the current price of the security. The semi strong form of the EMH describe that the current security prices are fully incorporates the all available information by the public, that not only includes the past price of the security but also on the basis of the reported data on financial/income statements, earnings, dividend announcements, any merger plan, liquidity situation etc. public information does not means that only the firm's financial information its includes all other information that relates/impact directly or indirectly to the firms performance.The strong form of EMH describe the security price which contains all information such as private as well as public. If the market is not informationally efficient net gain from the capital market is zero for the economy, since one group of investors earn abnormal gain at the cost abnormal loss of other group of investors.

\subsection{Problem Statement}

The investments or inflows in stock exchange are from individual, foreign and from Asset Management Companies (AMCs). AMCs are manage/invest the funds in stock that invested by the individuals in equity funds and these inflows are in heavy quantum of shares / trading volume or in amount that effects in the market change in index. So, we find out the impact of mutual fund Return (stock funds) as well as impact of macro state factor on PSX return. The objective of this research is to find out the impact of mutual fund flows and macro state factors on stock market and also to find out its impact on Pakistan Stock Exchange (PSX) return.

This study signifies the mutual fund industry of Pakistan and describes the impact of mutual fund industry on PSX. In due all contexts if down fall of mutual fund industry in Pakistan what will be effect of this downfall on stock market? The purpose of this research is to find the impact of mutual fund flows and macro state factors on stock market. In this research we find out the impact of mutual fund return (stock funds) on PSX return and also try to know the impact of macro state factor on PSX.

\subsection{Hypothesis}

H1: $\quad$ Equity Fundaffects significantly the Stock Return

H2: $\quad$ Debt Funds affects significantly the Stock Return

H3: $\quad$ Bond Return affects significantly the Stock Return

H4: $\quad$ T-Bills Return affects significantly the Stock Return

\section{LITERATURE REVIEW}

Fama and MacBeth (1973), made study on empirical test on Risk, Return and Equilibrium and test the impact of averages profit and risk for common stocks of New York Stock Exchange. In this theoretical test there are two models are used that is portfolio and market equilibrium model and the data is used in this study are the monthly percentage return for all common stocks return during 26 to 68 of New York stock exchange. It is concluded that the positive tradeoff between risk and return, the investor should assume about the relationship between the security risk and portfolio return is liner as implicit by the two parameter model. Malkiel (1992), conducted detailed study on return of investing in equity mutual funds and analyze the equity fund return during 1971 to 1991, it utilizes the data set of equity mutual fund from each year of the period. It is concluded that the equity mutual fund 
does not provide any license to believe on that the security market is most efficient. Most of the investor purchase the security on low price or chose the active and hot hand fund manager that seems to result in the good equity mutual fund return.

Fama and French (1992), made detailed study on cross section expected stock return that can easily measure book to market equity, weightage/size and variables. The data is to use in this study is from of intersection of all non-financial firms of NYSE, AMEX and NASDAQ. It is concluded that the result seems contradict from 1941 to 1990 , and found that the positive reliable association between average return. Jegadeesh and Titman (1993), made study on the strategies of to buy those stocks that have well performed in past periods and sell those stocks that performed poor and generate stock return over the period of six to twelve months. The sample size is taken in this research to analyze the data are for the period of 6 to twelve months of mutual fund returns. He concluded that the profitability strategy is not due to that the systematic risk; it is the part of the abnormal return is after the formation of the portfolio for the first year. Falkenstein (1996) studied on the stock characteristics preference by mutual funds holding; it is investigating the cross section of holding of mutual funds and shows that the mutual fund has significant impact on stocks. This research documents that the US open end mutual fund has revealed various stocks characteristics. The data is produced by inclusion open end mutual fund portfolio holding information; the data set contains holding of portfolio 2,284 and 2,520 of mutual fund during 1991 to 1992 respectively. It is concluded that the mutual funds act fewer like insider and most like the general public, individual investors are generally face disadvantage in trading liquidity. Carhart (1997), made detailed study on Persistence in Mutual Fund Performance in performance of mutual fund the expense has negative impact on fund performance and the turnover is also the same impact of performance of mutual fund. Monthly equity funds data are used in this study from 1962 to 1993. The concluding remark of this article shows the three basic principles for mutual fund investors, which are, avoid to investment in those funds whose performance is poor presently, fund that presently gave higher return is expected to give higher than average return in next year but it's not means that the year thereafter and the fee charges of funds are the i.e. front end load, back end load, transaction cost etc. are affect the fund performance directly.

Barber and Odean (2000), made detailed study on the individual investors and investment performance of common stocks and explore the investment performance of stocks that are directly held by households. For the objective of this it analyzes the data set of six year trading data of stocks activity of 78,000 household traded stocks. It is concluded that the gross return earned by the household is quit ordinary because of set of all costs with the selling price; net gain earned by the household is very poor. The average household stocks turnover rate is approximately seventy-five percentages annually; the average performance is traced due to cost associated with the high level of trading. Goetzmann and Massa (2003), were conducted study on Index Fund and Stock Market Growth. In this regard they use the two years' flows (daily) of the three major funds to analyze the association between asset price and volatility of index funds. The study based on the three reliable index funds that are Spartan U.S. Equity Fund Index, Spartan Market Index and VIP Market Index for the period 1993 to 1997, the asset values of these index funds are 12.9, 5.8 and 3.0 billion dollars respectively. In this research the regression method is used to analyze the data and they concluded that, the set of large standard and poor index funds suggested that, the demand may influence to the return, by the using of high frequency of data the investors respond on the basis of the past return of the fund. The investor trend is witnessed that, the investor attitude towards selling the shares when market goes down but not buy when index 
appreciated. It is also concluded that the return is also depended on inflow of the fund and as well outflow of the fund, but it may be permanent or weekly horizon.

Cooper, Gutierrez, Jr. and Marcum (2005), made study on the real time predictability of stock return and examine on the basis of cross sectional patterns the return of stock is obvious in real time without the benefit of observation. It uses the data of $\mathrm{NYSE}^{1}, \mathrm{AMEX}^{2}$ and $\mathrm{NASDAQ}^{3}$ non-financial listed firms for security prices research of return of stock on monthly basis from 1963 to 1997. It uses the regression based analysis and concluded that the return of stock is predictable by chance. The debate about the predictability is all about the mispricing of the script that increases the level of risk. The finding shows that the level of predictability is significantly lower than the previous believed.

Noulas, Papanastasiou and Lazaridis (2005), made detailed study on mutual fund performance the determination is to examine the equity mutual fund performance during the period of 1997 to 2000 and the weekly data set are used in this study for the same period of equity mutual funds. It is use the method to evaluate the data that are developed by Treynor and Jensen. It is concluded that on the basis of the sample result of four years, the first three years' data shows that the positive equity fund return while in the fourth year due to the fall of stock market. The result also concluded that the high risk is associated with the high return.

Comer (2006), made study on the Hybrid Mutual Fund and Market Timing Performance and examines the timing ability of stock market of sample of two hybrid mutual funds. It uses the multi factor timing model methodology and the sample data is used between 1992 to 2000 composed of 158 hybrid mutual funds the inclusion criteria is 1981 samples from each hybrid mutual fund. It is concluded that the bond timing variable and index substantially different from the market timing performance of fund sample over 1992 to 2000.

Hameed and Kusnadi (2006), conducted study on stock return and market condition in Japan. In this study it is use the time series variation to be dependent in price adjustment return on market information present good or bad news. Miller (1997) and Jones and Lamout (2002) also suggested that the adverse market information is fully integrated into stock prices. The incorporated data is set includes the daily market return and individual stock return, monthly trading activity and yearly market capitalization for all Japanese securities listed on Tokyo Stock Exchange over the period of 1979 to 1998, it is use the descriptive method to extract the result. It is concluded that the short selling and transaction cost immediately foil the stock prices that reflection negative information. To increase the market value market value, it is necessary to decrease abnormal stock trading volume both long and short term horizon. Beaumont, Daele, Frijns, Lehnert and Muller (2008), investigating the mutual fund flows and its impact on returns and volatility, the objective of this study is to explore the effect of shareholder sentiment on US stock market and it is measured by inflow and outflow of the money circulation domestically in US mutual funds. The methodology is used in this study is autoregressive conditional hetero scedasticity (GARCH)-in-mean specification. It is concluded that the fund flows and market return has a strong positive relationship on the basis of the market sentiment. High significant sentiment between funds flow and stock market return are concluded for the six-year period and the result suggested that the small portfolios are more affected rather than the big portfolios. Deb and Mukherjee (2008), made 
study on development of stock market that cause of growth of economic the objective of this is study is test the relationship between the economic growth and stock market department for the Indian economy. The technique was applied in this study is unit root tests and the long run Granger non-causality test proposed by Toda and Yamamoto (1995), this study test the relationship between the real gross domestic product growth rate and with the three stock market developments. The study concludes that there exists bi-directional causal effect between real market capitalization and the economic growth.

Rubio, Hassan and Merdad (2012), made study on international and Islamic mutual funds and its performance measurement, the determination of this study is to explore the whether investors that have first choice is to invest in Islamic mutual funds can avail limited portfolio efficiency opportunity due to the limited assets universe. The sample size is taken in this study for 143 Islamic mutual fund's net asset value accessible in Saudia Arabia during the period of January 2003 to December 2010. The researcher concluded that the Islamic investors have limited resources due to the Shariah and Ethical investment venue and preferring lesser risky funds. The financial crises of 2007-2008 originated due to the high investment in toxic assets and the investor of Islamic assets were avoided it. Qiang and Lacey (2013), made study on factor drives on mutual fund flows profit or panic, the determination is to study the market timing ability and the investor of mutual funds are how manage the allocation of their funds in response to the volatility of the market. The sample data is considered in this study is to US equity funds existed in any month during the period of 1992 January to 2008 December. This study concluded that investors of mutual fund on the whole are driven by the market volatility and they have not the ability to avoid the unfortunate loss to time the return of the market on the basis of the volatility, but the result also concluded that the small number of investors have the skill to adjust the return on the basis of the market timing.

Dash and Mahakud, (2015), made detailed study on anomalies of stock market, return and asset pricing, the determination of this study is to explore the use of unconditionally and conditionally asset pricing model that cover the asset pricing anomalies in emerging market of India. For measure the risk adjusted return it use the time series regression approach and to examine the predictability of firm characteristics it uses the panel data estimation technique is used. It is concluded that presence of significant asset pricing effect in the development of stock market and exploit the investment strategy.

Hili, Pace and Grima (2016), made study on performance evaluation of equity mutual funds the purpose of this study is to explore insight on portfolio of US, European and Emerging Markets equity mutual funds that objective is to investment in emerging markets. The data set is made is of 137 equity mutual funds during January 2004 to December 2014 and use the regression model to analyze the data set. It is concluded that the large equity fund portfolio has beat the small and medium size portfolio competitors. The risker fund generates the high return and investor should accept the high risk for the hope of the high return in emerging markets.

Devaney, Morillon and Weber (2016), made study on risk and return and tradeoff in the production and mutual fund efficiency. The study compares fund performance to the best practices, it uses the projection pricing method. The researcher uses the data of over 260 European mutual fund industries and found that there is no liner correlation between fund size and fund performance. It is also using the five years' risk adjusted return of 188 mutual funds during 2000 to 2014 reported by morning star to analyze the fund returns. It is 
concluded that if the mutual fund industry adopts new technology than enable to reduce the risk and maximize the risk adjusted return, improve fund performance and taking less risk and generate low return but with lesser risk. Alverio and Rodríguez (2016), made study on firm pricing and propensity to go public, the study focuses on valuation of US private firms holding on mutual funds. This study uses the evaluation methodology to analyze the data set and it is concluded that, private firm common stocks prices are fluctuating more that preferred stock. Mutual funds place most of their capital to US private sector firms.

\section{DATA AND METHODOLOGY}

\subsection{Data collection}

Panel data for 10 Asset Management Companies (AMCs) has been taken for 10 (2007 to 2016) years which includes equity and income funds return, PSX return and return of macro state factors Therefore, the sample size of 100 observations is used in this study to analyze the results. The data has been extracted from the web site of MUFAP, PSX and SBP web site.

\subsection{Statistical Techniques}

Panel Regression is applied to test the hypothesis of this study. Furthermore, random and fixed effect model are analyzed and comparison among PLS, Random Effect Model (REM) and Fixed Effect Model (FEM).

\subsection{Research Model}

The research model that would be helpful to understand about the dependent and independent variable. Stock return is dependent variable and equity funds return and macro state factors are the independent variables. The conceptual framework for the model will be:

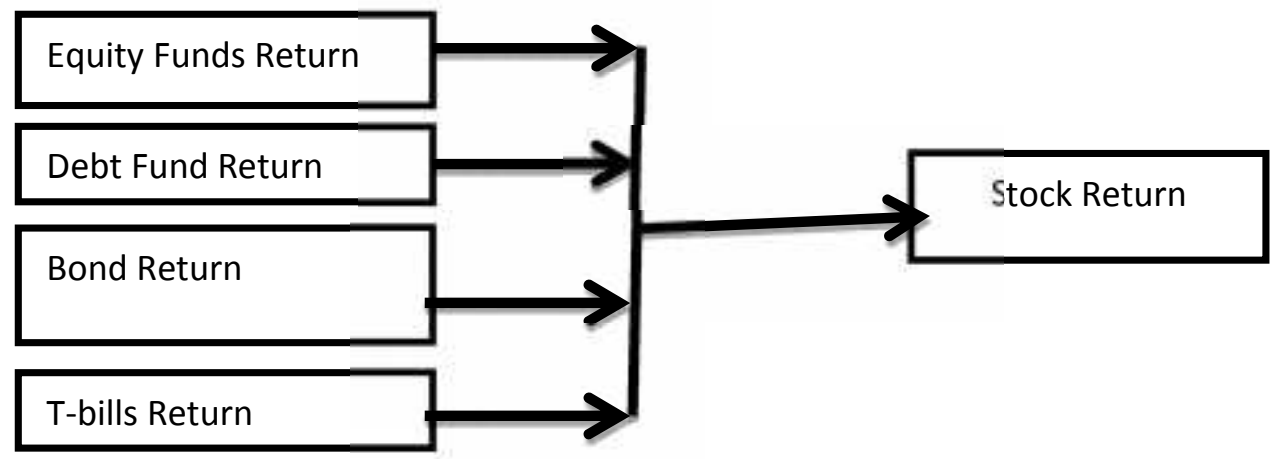

Fig 3.1: Conceptual Model

The equations for the models may be such as:

$Y=\alpha+\beta X+\mu$

For stock return:

$S R=\alpha+\beta_{1} E F R+\beta_{2} D F R+\beta_{3} D R+\beta_{4} T B R$ 
Here:

SR: $\quad$ Stock Return

EFR: $\quad$ Equity Fund Return

DFR: Debt Fund Return

BR: $\quad$ Bond Return

TBR: Treasury Bill Return

\section{RESULTS AND INTERPRETATIONS}

In this section the panel data analysis has been applied to test the hypotheses of the study. The schedule of the data analysis in this part are, first we will discuss Panel Least Square and then random and fixed effect model. The following results are computed through EViews

Table 4.1 PLS

Dep Var: STOCK_RETURN

Method: PLS

\begin{tabular}{lrrrr}
\hline \hline \multicolumn{1}{c}{ Variable } & Coefficient & Std. Error & t-Statistic & Prob. \\
\hline \hline RETURN_EQUITY_FUNDS & 0.9985 & 0.0744 & 13.407 & 0.0000 \\
BONDS_RETURN & -3.0334 & 2.8549 & -1.0625 & 0.2910 \\
DEBT_FUNDS_RETURN & 0.1286 & 0.4002 & 0.3214 & 0.7486 \\
TBILLS_RETURN & 2.6054 & 2.7460 & 0.9488 & 0.3454 \\
C & 4.7138 & 8.1543 & 0.5780 & 0.5647 \\
\hline \hline
\end{tabular}

Cross-section fixed (dummy variables)

\begin{tabular}{lrll}
\hline \hline R-sq & 0.719729 & Mean dep var & 17.44907 \\
Adj R-squ & 0.677362 & S.D. dep var & 26.45523 \\
S.E. (reg & 15.02690 & Akaike info criterion & 8.386738 \\
Sum squ res & 19419.46 & Schwarz criterion & 8.751462 \\
Log likelihood & -405.3369 & Hannan-Quinn criter. & 8.534348 \\
F-stat & 16.98811 & DW stat & 2.306659 \\
Prob (F-stat) & 0.000000 & & \\
\hline \hline
\end{tabular}

\subsection{Hypothesis Testing}

\section{Estimated Regression Equation}

Stock Return $i t=4.7138+0.9985$ Return Equity Funds $i t+3.0334$ Bond Return $_{i t}+$ 0.1286 Debt Fund Return $i t+2.6054$ T-bills Return $i t$

The variables included in this study are the Stock Return, Return of Equity Funds, Bond Return, Debt Funds Return and T-bills Return. 


\section{H1: Equity Funds affects significantly the Stock Return.}

The probability value for equity funds return are less than 0.05 which is 0.000 and the coefficient of respective variable is 0.99 which is positive, so we reject the null hypothesis. It means that the mutual funds return has significant impact of stock return. Fama and French (1992), studied on "The Cross-Section of Expected Stock Returns", and concluded that the equity fund return has positively related to the stock return. This is due to the fact that the injection of funds in equity market are seems to effect positive or enhance the index in change that resultant for the growth of stocks as well for the equity funds of mutual fund industry.

\section{H2: Debt Funds affect significantly Stock Return}

The probability value of debt fund returns is 0.74 which is greater than 0.05 and the coefficient is 0.12 so we fail to reject the null hypothesis. It means that the debt fund has insignificant impact on stock returns. The study of Edwards (2008), investigated the causal relation between the mutual funds (equity and bond mutual fund flows) and returns (stock and bond returns). It is concluded that, there is no evidence found of connection of bond fund return on bond return its means that there is insignificant effect on stock return of debt fund, T-bills and debt return.

\section{H3: Bond Return affects significantly Stock Return}

The probability value of bond / debt return is 0.29 which is greater than 0.05 and the coefficient is -0.03 so we accept the null hypothesis and reject the alternative hypothesis. It mean that the bond / debt return has insignificant impact on stock returns.

\section{H4: T-Bills Return affects significantly Stock Return}

The probability value of bond / debt return is 0.34 which is greater than 0.05 and the coefficient is 2.60 so we accept the null hypothesis and reject the alternative hypothesis. It's mean that the T-bills return has insignificant impact on stock returns.

The R-square value is 0.71 which is greater than 0.5 , it indicates that the model is fit and suggested that the independent variables included in the model are explained $71 \%$ in the dependent variable.

\subsection{Analysis of Fixed and Random Effects Models with comparison}

\section{Fixed Effect Model (FEM)}

The equation for FEM is as follows:

\section{Equation for Fixed Effect Model}

$S R_{i t}=\alpha_{i}+\beta_{1} E F R_{i t}+\beta_{2} D F R_{i t}+\beta_{3} D R_{i t}+\beta_{4} T B R_{i t}+\varepsilon_{i}$

Where:

$\alpha_{i}=\alpha+F_{i}$

Here $F_{i}$ denotes the value of unobserved variable

$\alpha_{i}=\alpha+F_{i}$ 
$\left(\alpha+\right.$ EffectValue $_{i}$

Hence, the final equation for the FEM shall be as follows:

$S R_{i t}=\left(\alpha+{\left.\text { Effect } \text { Value }_{i}\right)+\beta_{1} E F R_{i t}+\beta_{2} D F R_{i t}+\beta_{3} D R_{i t}+\beta_{4} T B R_{i t}+\varepsilon_{i}}\right.$

Table 4.2 Fixed Effects

Cross-section fixed effects test equation:

Dep Var: STOCK_RETURN

\begin{tabular}{lrlrlr}
\hline \hline \multicolumn{1}{c}{ Variable } & Coefficient & & Std. Error & t-Statistic & Prob. \\
\hline \hline RETURN_EQUITY_FUNDS & 0.973089 & 0.072130 & 13.49075 & 0.0000 \\
BONDS_RETURN & -2.500519 & 2.789386 & -0.896441 & 0.3723 \\
DEBT_FUNDS_RETURN & 0.031857 & 0.372547 & 0.085510 & 0.9320 \\
TBILLS_RETURN & 2.064148 & & 2.682093 & 0.769604 & 0.4434 \\
C & 5.722099 & & 7.950698 & 0.719698 & 0.4735 \\
\hline \hline R-sq & 0.702144 & & Mean dep var & 17.44907 \\
Adj R-sq & 0.689602 & S.D. dep var & 26.45523 \\
S.E. of reg & 14.73909 & Akaike & & 8.267591 \\
Sum sq res & 20637.89 & Schwarz & 8.397849 \\
Log likelihood & -408.3795 & Hannan-Quinn criter. & 8.320309 \\
F-stat & 55.98643 & DW stat & & 2.191968 \\
Prob (F-stat) & 0.000000 & & &
\end{tabular}

Table 4.3 Fixed Effect Values for the Sample Asset Management Companies

\begin{tabular}{|clc|}
\hline & AMC & Effect \\
\hline $\mathbf{1}$ & Al Meezan & -2.776339 \\
\hline $\mathbf{2}$ & UBL & -0.066332 \\
\hline $\mathbf{3}$ & NAFA & -2.008880 \\
\hline $\mathbf{4}$ & JS & -0.274853 \\
\hline $\mathbf{5}$ & Atlas stock market fund & -0.400982 \\
\hline $\mathbf{6}$ & MCB Pak Stock Market Fund & -0.631421 \\
\hline $\mathbf{7}$ & Picic Inv Fund & 7.020947 \\
\hline $\mathbf{8}$ & Al Falah & -5.647739 \\
\hline $\mathbf{9}$ & HBL Asset Management & 5.700336 \\
\hline $\mathbf{1 0}$ & National Investment Trust & -0.914735 \\
\hline
\end{tabular}

Fixed Effect Model for first AMC (i.e. Al Meezan Investment Management Limited taken from above table 4.3) would be:

$$
S R_{i t}=(5.722-2.776)+0.973 E F R_{i t}-2.5005 D F R_{i t}+0.0318 D R_{i t}+2.041 T B R_{i t}
$$

The value of F-statistic value(55.98) is higher than 3.84, which suggests that FEM is fit. It can also be traced from the P-Value which is also significant. 


\section{Random Effect Model (REM)}

The REM assumes that individual Banks have the random or the time invariant attributes which do not correlate with the independent variables.

\section{Equation for Random Effect Model}

$S R_{i t}=\alpha_{i}+\beta_{1} E F R_{i t}+\beta_{2} D F R_{i t}+\beta_{3} D R_{i t}+\beta_{4} T B R_{i t}+\mu_{i}$

Table 4.4 Random Effect (Panel EGLS)

Dep Var: STOCK_RETURN

Method: Panel EGLS (Cross-section random effects)

\begin{tabular}{lrrrr}
\hline \multicolumn{1}{c}{ Variable } & Coefficient & Std. Error & t-Statistic & Prob. \\
\hline \hline RETURN_EQUITY_FUNDS & 0.973089 & 0.073539 & 13.23237 & 0.0000 \\
BONDS_RETURN & -2.500519 & 2.843854 & -0.879271 & 0.3815 \\
DEBT_FUNDS_RETURN & 0.031857 & 0.379822 & 0.083872 & 0.9333 \\
TBILLS_RETURN & 2.064148 & 2.734465 & 0.754864 & 0.4522 \\
C & 5.722099 & 8.105949 & 0.705914 & 0.4820 \\
\hline
\end{tabular}

Cross-section random $0.000000 \quad 0.0000$

Idiosyncratic random

$15.02690 \quad 1.0000$

\begin{tabular}{lcll}
\hline \hline \multicolumn{4}{l}{ Weighted Statistics } \\
\hline \hline R-sq & 0.702144 & Mean dep var & 17.44907 \\
Adj R-sq & 0.689602 & S.D. dep var & 26.45523 \\
S.E. of reg & 14.73909 & Sum squared resid & 20637.89 \\
F-stats & 55.98643 & DW stat & 2.191968 \\
Prob (F-stats) & 0.000000 & & \\
\hline \hline & Unweighted Statistics & \\
\hline \hline R-squared & 0.702144 & Mean dep var & 17.44907 \\
Sum squared resid & 20637.89 & DW stat & 2.191968 \\
\hline \hline
\end{tabular}

The value of F-statistic value (55.9864) shows that the model is significant 


\subsection{Comparison among PLS, FEM and REM}

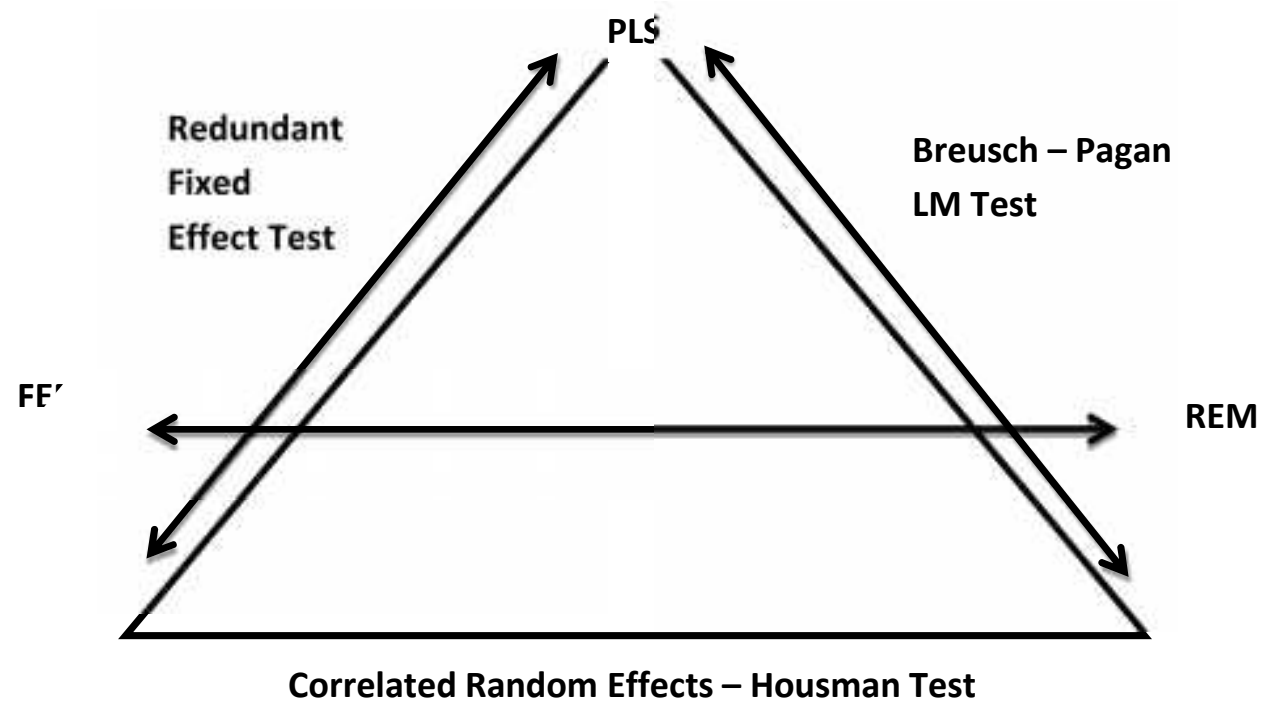

Above figure 1.1 shows the techniques for the comparison among PLS, FEM and REM.

The PLS and FEM will be comparedvia Redundant Fixed Effects Test. The FEM with REM will be compared via Correlated Random Effects - Hausman Test.

\section{Comparison between PLS and FEM Models}

Redundant Fixed Effects Test is applied to compare the appropriateness of PLS and FEM. The hypotheses of Redundant Fixed Effects Test are:

H0: PLS is efficient and consistent

$\mathrm{H} 1$ : FEM is efficient and consistent

Table 4.5 Fixed Effects Tests

Redundant Fixed Effects Tests

\begin{tabular}{|c|c|c|c|}
\hline Effects Test & Statistic & d.f. & Prob. \\
\hline Cross-section F & 0.599538 & $(9,86)$ & 0.7941 \\
\hline Cross-section Chi-square & 6.085269 & 9 & 0.7314 \\
\hline
\end{tabular}

Cross-section fixed effects test equation:

DV: STOCK_RETURN

\begin{tabular}{lrrrr}
\hline \hline \multicolumn{1}{c}{ Variable } & Coefficient & Std. Error & t-Statistic & Prob. \\
\hline \hline RETURN_EQUITY_FUNDS & 0.973089 & 0.072130 & 13.49075 & 0.0000 \\
BONDS_RETURN & -2.500519 & 2.789386 & -0.896441 & 0.3723 \\
DEBT_FUNDS_RETURN & 0.031857 & 0.372547 & 0.085510 & 0.9320 \\
TBILLS_RETURN & 2.064148 & 2.682093 & 0.769604 & 0.4434 \\
C & 5.722099 & 7.950698 & 0.719698 & 0.4735 \\
\hline \hline R-sq & 0.702144 & Mean dep var & 17.44907
\end{tabular}


Adj R-sq

S.E. of reg

Sum sqres

Log likelihood

F-stats

Prob
0.689602

14.73909

20637.89

$-408.3795$

55.98643

0.000000
26.45523

8.267591

8.397849

8.320309

2.191968

The P-Value in the table 4.5 (Cross-section F) is 0.7941 which is hence, the Fixed Effect Model (FEM) is not appropriate.

\section{Comparison between REM and FEM Models}

Hausman Test is used to test the comparison of REM and FEM.

The hypotheses of Hausman Test are:

H0: REM is efficient and consistent or $H_{0}: \operatorname{Cov}\left(X_{i}, U_{i}\right)=0$

H1: FEM is efficient and consistent or $H_{1}: \operatorname{Cov}\left(X_{i}, U_{i}\right) \neq 0$

Table 4.6 Hausman Test (Random Effects)

Correlated Random Effects - Hausman Test

Equation: Untitled

Test cross-section random effects

\begin{tabular}{llrr}
\hline \hline Test Summary & $\begin{array}{r}\text { Chi-Sq. } \\
\text { Statistic }\end{array}$ & Chi-Sq. d.f. & Prob. \\
\hline \hline Cross-section random & 0.000000 & 4 & 1.0000 \\
\hline \hline
\end{tabular}

In the above illustration, the P-value (Cross-section random) is 1.0000, which is significant, hence, the REM is appropriate.

Table 4.7 Specification Tests for Best Model Selected

\begin{tabular}{|l|c|cl|}
\hline \multicolumn{1}{|c|}{ Specification Tests } & Comparison & Prob. & Sel \\
\hline Redundant Fixed Effects Tests & PLS/FEM & 0.7941 & PLS \\
\hline \hline Correlated Random Effects - Hausman Test & FEM/REM & 1.0000 & REM \\
\hline
\end{tabular}

Table 4.7 is based on the results of Redundant Fixd Effects and Hausman Test. Fixed effect test suggest that FEM is insignificant and likewise the Hausman Test also portrays that FEM is insignificant and hence REM is efficient. The adjusted R Square and F-stats of REM model are higher than PLS, therefore, the results of REM shall be considered for hypothesis testing. 
Table 4.8 Summary of Statistical Tests

\begin{tabular}{|lrrr|}
\hline \multicolumn{1}{|c}{ Variable } & PLS Model & \multicolumn{1}{c|}{ FEM Model } & \multicolumn{1}{c|}{ REM Model } \\
\hline C & 4.7138 & 5.7220 & 5.7220 \\
& $0.5780)$ & $(0.719698)$ & $(0.705914)$ \\
\hline Return Equity Funds & 0.9985 & 0.9730 & 0.9730 \\
& $(13.407)$ & $(13.49075)$ & $(13.23237)$ \\
\hline Bond Return & $-3.0334^{*}$ & $-2.5005^{*}$ & $-2.5005^{*}$ \\
& $(-1.0625)$ & $(-0.896441)$ & $(-0.879271)$ \\
\hline Debt Fund Return & 0.1286 & $0.0318^{*}$ & $0.0318^{*}$ \\
& $(0.9488)$ & $(0.085510)$ & $(0.083872)$ \\
\hline T-Bills Return & 2.6054 & 2.0641 & 2.0642 \\
& $(2.7460)$ & $(0.769604)$ & $(0.754864)$ \\
\hline R-squared & 0.7197 & 0.7021 & 0.7021 \\
\hline Adjusted R-squared & 0.6773 & 0.6896 & 0.6896 \\
\hline F-statistic & 16.9881 & 55.9864 & 55.9864 \\
\hline Durbin-Watson stat & 2.3066 & 2.1919 & 2.1919 \\
\hline Redundant Fixed Effects Tests & Cross-section F & & \\
& 0.7941 & Prob. & \\
\hline Correlated Random Effects - & Chi-Sq. Statistic & 1.0000 & \\
\cline { 2 - 4 } Hausman Test & 0.00000 & & \\
\hline Significance at: $*$ for $<0.01$, Figures in Brackets are Standard Errors Robust to & \\
Heteroscedasticity. & & & \\
\hline
\end{tabular}

All three models are summarized in Table 4.8. The results of REM shall be considered for hypothesis testing since FEM is insignificant and REM has higher R square and F-Stats than PLS. The results may be concluded as: Equity Fund Returns has significant positive effect on the stock market returns, whereas the Debt Fund Return, Treasury Bill Returnand Bond Return have insignificant effects on the stock returns.

Table 4.9 summarizes the hypothesis testing as concluded after the technical interpretation of the statistical results.

Table 4.9Hypotheses Assessment Summary

\begin{tabular}{|c|c|c|c|c|}
\hline S. No. & Hypothesis & t-values & P-values & $\begin{array}{c}\text { Empirical } \\
\text { Conclusion }\end{array}$ \\
\hline $\mathbf{1}$ & H1: Equity Fund affects significantly the Stock \\
Return & 13.23 & 0.000 & Accept \\
\hline $\mathbf{2}$ & $\begin{array}{c}\text { H2: Debt Fund Return affects significantly Stock } \\
\text { Return. }\end{array}$ & -0.879 & 0.3815 & Reject \\
\hline $\mathbf{3}$ & H3: Bond Return affects significantly Stock \\
Return. & 0.0838 & 0.9333 & Reject \\
\hline \hline $\mathbf{4}$ & $\begin{array}{c}\text { H4: T-Bills Return affects significantly Stock } \\
\text { Return. }\end{array}$ & $\mathbf{0 . 7 5 4 8}$ & $\mathbf{0 . 4 5 2 2}$ & Reject \\
\hline
\end{tabular}




\section{DISCUSSION, CONCLUSION \& RECOMMENDATION}

\subsection{Discussion and Conclusion}

The purpose of this research is to find the impact of mutual fund flows and macro state factors on stock market. In this research we find out the impact of mutual fund return (stock funds) on PSX return and also try to know the impact of macro state factor on PSX.A sample size was contained of 100 observations that are used in this study to analyze the results. Panel Regression is applied to test the hypothesis of this study.

The study concluded that the there is significant effect of Equity Funds on Stock Return. On the other hand, debt funds return and macro state factors have the insignificant impact on Stocks Return. It has been concluded that, the injection of funds in Equity Funds is significantly improve the Stock Returns due to the bulk buying of stocks that attract the local buyer as well to participate in stock funds or stock, on the other hand debt fund return and macro state factors could have insignificant impact on stock returns.

\subsection{Recommendation}

The following are some of the suggestions or recommendations which can effect significantly and consistent growth of Stocks or Stock Returns.

- The regulatory of mutual funds is strictly monitor of injection and withdrawal of funds in stock funds that are directly proportionate with the stock and can affect the stocks future returns.

- Create a mechanism of buying and selling cap of each stocks.

- Regulatory are required to ensure the not creating any bubble in stocks by the fund managers or brokers.

- The share of stock funds in capital market should be adequately utilize in profitable opportunities to increase the profitability of participants of the fund and the investors.

\section{REFERENCES}

Allaudeen Hameed and Yuanto Kusnadi, (2006), "Stock Return Cross-Autocorrelations and Market Conditions in Japan", The Journal of Business, Vol. 79, No. 6 (2006), pp. 3029-3056

Alverio and Rodríguez, (2016),"Private firm pricing and propensity to go public: evidence from mutual funds holdings", The Journal of Risk Finance, Vol. 17 Iss 3 pp. 328 346.

Burton G. Malkiel, (1995), "Return from Investing in Equity Mutual Funds 1971 to 1991", The Journal of Finance, Volume 50, Issue 2, 549-572.

Barber and Odean (2000), "Trading Is Hazardous to Your Wealth: The Common Stock Investment Performance of Individual Investors" The Journal of Finance, Vol. LV, NO. 2.

Beaumont, Daele, Frijns, Lehnert and Muller (2008), "Investor sentiment, mutual fund flows and its impact on returns and volatility", Managerial Finance, Vol. 34 Iss 11 pp. 772 -785 .

Deb and Mukherjee (2008), "Does Stock Market Development Cause Economic Growth? A Time Series Analysis for Indian Economy", International Research Journal of Finance and Economics, ISSN 1450-2887 Issue 21. 
Dash and Mahakud, (2015), Market anomalies, asset pricing models, and stock returns: evidence from the Indian stock market", Journal of Asia Business Studies, Vol. 9 Iss 3 pp. $306-328$.

Devaney, Morillon and Weber, (2016),"Mutual fund efficiency and tradeoffs in the production of risk and return", Managerial Finance, Vol. 42 Iss 3 pp.

Edwards and R., The New Finance: Regulation and Financial Stability, Washington DC: AEI Press, 1996.

Eric G. Falkenstein (1996), "Preference for Stock Characteristics as Revealed by Mutual Fund Portfolio Holding", The Journal of Finance, Volume 51, Issue 1, 111-135.

Eugene F. Fama and James D. MacBeth, (1973) "Risk, Return and Equilibrium: Empirical Test" The Journal of Political Economy", Volume 81 No.3, 607-636.

Eugene F. Fama and Kenneth R. French, 1992 "The Cross Section of Expected Stock Return", The Journal of Finance, Vol 47, No. 2, (June 1992), 427-465.

George Comer, (2006), "Hybird Mutual Fund and Market Timing Performance", The Journal of Business, Volume 79, No. 2, pp. 771-779.

Fama, Eugene (1965). "The Behavior of Stock Market Prices". Journal of Business 38: 34 105.

Fama, E; French, K (1992). "The Cross-Section of Expected Stock Returns". Journal of Finance. 47: 427-465

G. Noulas, A., A. Papanastasiou, J., \& Lazaridis, J. (2005). Performance of mutual funds. Managerial finance, 31(2), 101-112.

Hili, Pace and Grima (2016),"Equity Mutual Fund Performance Evaluation: An Emerging Market Perspective" In Contemporary Issues in Bank Financial Management, Published online, 93-132.

Mark M. Carhart, (1997), "On Persistence in Mutual Fund Performance", The Journal of Finance, Volume 52, Issue 1, 57-82.

Michael Cooper, Roberto C. Gutierrez, Jr. and Bill Marcum, (2006) "On the Predictability of Stock Returns in Real Time” The Journal of Business, Vol. 78, No. 2 (March 2005), pp. 469-500.

Narasimhan Jegadeesh and Sheridan Titman (1993), "Returns to Buying Winners and Selling Losers: Impact for stock market efficiency", The Journal of Finance, Volume 48, Issue 1, 65-91.

Noulas, Papanastasiou and Lazaridis, (2005),"Performance of mutual funds", Managerial Finance, Vol. 31 Issue 2 pp. $101-112$

Rubio, Hassan and Merdad, (2012),"Non-parametric performance measurement of international and Islamic mutual funds", Accounting Research Journal, Vol. 25 Iss 3 pp. $208-226$.

Qiang and Lacey, (2013),"What drives mutual fund flows: profit or panic?" Review of Accounting and Finance, Vol. 12 Issue-1 pp. 4 - 22.

William N. Goetzmann and Massimo Massa, (2003) "Index Funds and Stock Market Growth “, The Journal of Business, Vol. 76, No. 1 (January 2003), pp. 1-28 